\title{
Pengaruh Penggunaan Dedak Fermentasi Terhadap Kandungan Bahan Kering dan Bahan Organik Silase Rumput Gajah (Pennisetum Purpureum)
}

\author{
The Effect of Fermented Bran Usage on Dry Matter and Organic Matter Content of Elephant Grass (Pennisetum \\ Purpureum) Silage
}

\author{
Nisa Husnul Azizah*, Budi Ayuningsih², lin Susilawati \\ 1Program Studi Fakultas Peternakan, PSDKU Universitas Padjadjaran Pangandaran \\ 2 Fakultas Peternakan Universitas Padjadjaran
}

\begin{abstract}
Abstrak
Silase merupakan teknologi pengawetan hijauan dengan cara anaerob. Dedak fermentasi dapat digunakan sebagai starter dalam pembuatan silase yang bertujuan untuk mempercepat proses fermentasi. Tujuan penelitian untuk mengetahui pengaruh penggunaan dedak fermentasi terhadap kandungan bahan kering dan bahan organik silase rumput gajah. Penelitian dilaksanakan pada bulan November 2019 - Januari 2020 di kelompok ternak Mekar Jaya, Dusun Cikangkung RT 01 RW 03, Desa Cikembulan, Kecamatan Sidamulih, Kabupaten Pangandaran dan analisis laboratorium dilaksanakan di Laboratorium Nutrisi Ternak Ruminansia dan Kimia Makanan Ternak Fakultas Peternakan Universitas Padjadjaran di Jatinangor Sumedang. Penelitian menggunakan metode eksperimental serta rancangan acak lengkap (RAL) dengan 3 perlakuan dan 6 ulangan. Perlakuan terdiri atas P1 (1\% dedak fermentasi), P2 (3\% dedak fermentasi) dan P3 (5\% dedak fermentasi). Data penelitian dianalisis menggunakan Analisis Varian (ANOVA). Hasil analisis menunjukkan bahwa perlakuan tidak nyata $(\mathrm{P}>0,05)$ mempengaruhi kandungan bahan kering dan bahan organik silase rumput gajah.
\end{abstract}

Kata Kunci: dedak fermentasi, bahan kering, bahan organik, rumput gajah, silase.

\section{Abstract}

Silage is an anaerobic preservation technology. Fermented bran can be used as a starter in making silage which aims to speed up the fermentation process. The purpose of this study was to determine the effect of fermented bran usage on dry matter and organic matter content of elephant grass silage. This research was conducted on 3 November 2019 - 15 January 2020 in the Mekar Jaya livestock group, Pangandaran Regency and laboratory analysis was carried out at the Ruminants Livestock Nutrition and Animal Food Chemistry Laboratory, Faculty of Animal Husbandry, Padjadjaran University in Jatinangor Sumedang. Exsperimental method was used with completely randomized design (CRD) with 3 treatments and 6 replications. The treatments consisted of P1 (1\% fermented bran), P2 (3\% fermented bran) and P3 (5\% fermented bran). Research data were analyzed using Variant Analysis (ANOVA). The analysis showed that the treatment did not significantly $(\mathrm{P}>0.05)$ affect the content of dry matter and organic matter silage of elephant grass.

Keywords: fermented bran, dry matter, organic matter, elephant grass, silage.

\section{PENDAHULUAN}

Ketersediaan hijauan pakan yang mencukupi dan memenuhi kebutuhan nutrien merupakan salah satu faktor penentu dalam usaha peternakan. Hijauan pakan memiliki peranan sangat penting dalam memenuhi kebutuhan ternak baik untuk hidup pokok, pertumbuhan, produksi, dan reproduksi. Ketersediaan hijauan pakan secara kontinyu sepanjang tahun bagi ternak masih menjadi permasalahan. Oleh karena itu, peternak harus mempunyai inovasi untuk mengantisipasi kekurangan hijauan pakan. Inovasi dapat dilakukan dengan membuat pakan fermentasi yang disebut dengan silase.
Silase merupakan teknologi pengawetan hijauan pakan dengan cara anaerob. Silase yang memiliki kualitas baik akan dihasilkan ketika fermentasi didominasi oleh bakteri yang menghasilkan asam laktat, sedangkan aktivitas bakteri clostridia jumlahnya rendah (Santoso, dkk., 2009). Asam laktat yang dihasilkan selama proses fermentasi akan berperan sebagai zat pengawet sehingga dapat mengurangi pertumbuhan mikroorganisme pembusuk.

Salah satu hijauan pakan yang berpotensi untuk bahan dasar pembuatan silase ialah rumput gajah. Rumput gajah memiliki kualitas dan gizi yang baik sebagai bahan pakan ternak terutama ruminansia. Tanaman ini dijadikan 
sebagai hijauan pakan karena memiliki produktivitas yang tinggi. Produktivitas rumput gajah varietas Hawaii berbulu mencapai berat segar 277 ton per hektar per tahun atau 36 ton per hektar per tahun dalam berat kering (Sinaga, 2007). Tanaman ini mampu hidup pada kondisi lahan yang kritis, dimana tanaman lain tidak dapat tumbuh dengan baik (Sanderson dan Paul, 2008). Rumput gajah merupakan rumput yang umum digunakan sebagai silase di daerah tropis (Webster dan Wilson, 1989). Produktivitas yang tinggi ini mampu dimanfaatkan untuk cadangan pakan pada saat kesulitan hijauan pada saat musim kemarau dengan mengolahnya menjadi silase.

Pembuatan silase yang baik bisa diupayakan dengan penambahan aditif. Aditif yang digunakan dalam pembuatan silase ialah dedak fermentasi. Dedak mengandung karbohidrat yang relatif tinggi yang dapat digunakan sebagai sumber energi bagi bakteri penghasil asam laktat. Dedak padi memiliki watersoluble carbohydrates 5,4\% (Despal dkk., 2011). Dedak padi yang mengandung watersoluble carbohydrates jika ditambahkan di dalam silase, akan meningkatkan fermentable carbohydrates untuk menyediakan lingkungan bagi berkembangnya bakteri pembentuk asam laktat dan penurunan $\mathrm{pH}$ silase (Nisa dkk, 2008; Saricicek dan Kilic, 2011). Dedak fermentasi berasal dari proses fermentasi dedak yang telah ditambahkan SOC (Suplemen Organik Cair) isi rumen dan molases dengan perbandingan 10:2: 1 .

SOC isi rumen yang ditambahkan pada dedak fermentasi merupakan cairan hasil fermentasi yang berasal dari isi rumen, tepung gaplek, dan molases yang di dalamnya terdapat bakteri asam laktat sebagai sumber inokulan. Adanya protein yang terdapat pada isi rumen menunjukkan bahwa bakteri yang terdapat dalam isi rumen berpotensi untuk memperbaiki kualitas pakan (Arlini, 2014). Tingginya kandungan karbohidrat sederhana yang terdapat pada tepung gaplek dapat digunakan oleh bakteri pembentuk asam laktat untuk menurunkan pH silase (Susetyo dkk., 1969). Penambahan molases pada pembuatan SOC bertujuan untuk mempercepat proses terbentuknya asam laktat dan sebagai penyedia sumber energi yang digunakan dalam proses fermentasi oleh bakteri (Eko dkk., 2012).

Dedak fermentasi mampu mempertahankan kandungan bahan kering dan bahan organik silase karena pada proses ini bakteri asam laktat berperan sebagai pengawet dan mampu menekan degradasi nutrien sehingga silase yang dihasilkan memiliki kandungan bahan kering dan bahan organik yang baik. Dedak fermentasi berperan sebagai akselerator yg dapat membantu mempercepat proses fermentasi, karena membantu menyediakan biakan bakteri asam laktat bagi proses fermentasi. Peningkatan bahan kering dan bahan organik silase berkaitan dengan kemampuan akselerator yang diinokulasikan pada bahan serta dapat menurunkan $\mathrm{pH}$ sehingga dapat menghambat pertumbuhan bakteri clostridia, dan menghambat degradasi nutrien, sehingga bahan kering dan bahan organik silase yang ditambahkan akselerator relatif lebih tinggi dibandingkan dengan silase yang tidak ditambahkan akselerator (Santoso, 2009). Akselerator mampu untuk menambahkan kandungan bahan kering sehingga mampu mengurangi kadar air pada silase (Kurnianingtyas, dkk., 2012).

Tujuan dari penelitian ini adalah untuk mengetahui pengaruh penggunaan dedak fermentasi terhadap kandungan bahan kering dan bahan organik silase rumput gajah serta untuk mengetahui dosis dedak fermentasi yang optimal dalam silase rumput gajah terhadap kandungan bahan kering dan bahan organik silase.

\section{METODOLOGI}

\section{Objek dan Metode}

Penelitian dilaksanakan pada tanggal 3 November 2019 15 Januari 2020 di kelompok ternak Mekar Jaya, Dusun Cikangkung RT 01 RW 03, Desa Cikembulan, Kecamatan Sidamulih, Kabupaten Pangandaran. Analisis laboratorium dilakukan di Laboratorium Nutrisi Ternak Ruminansia dan Kimia Makanan Ternak Fakultas Peternakan Universitas Padjadjaran di Jatinangor, Sumedang. Penelitian menggunakan metode eksperimental dengan rancangan percobaan Rancangan Acak Lengkap (RAL) dengan tiga perlakuan yaitu: $\mathrm{P} 1=$ Penggunaan 1\% dedak fermentasi; P2= Penggunaan 3\% dedak fermentasi; $\mathrm{P} 3=$ Penggunaan 5\% dedak fermentasi. Data hasil penelitian diuji dengan analisis ragam dan dilanjutkan dengan uji jarak berganda Duncan. Data penelitian diolah menggunakan program excel.

\section{Bahan Penelitian}

Rumput gajah diperoleh dari kebun kelompok ternak Mekar Jaya Pangandaran yang dipanen pada umur 40 hari sebanyak 200 kilogram. Dedak padi yang digunakan diperoleh dari gudang penggilingan padi yang berada di Dusun Gembor, Desa Cikembulan, Kecamatan Sidamulih, Kabupaten Pangandaran. Dedak yang dibutuhkan dalam penelitian adalah sebanyak 10 kilogram. Molases yang dibutuhkan dalam penelitian sebanyak 2 kilogram yang dibeli dari Pasar Parigi, Kabupaten Pangandaran. Molases digunakan sebagai bahan dalam pembuatan SOC dan dedak fermentasi. Isi rumen yang dibutuhkan dalam penelitian sebanyak 2 kilogram yang diperoleh dari tempat pemotongan hewan (TPH) yang berada di Parigi, Kabupaten Pangandaran. Isi rumen digunakan sebagai bahan utama dalam pembuatan SOC. Tepung gaplek yang dibutuhkan dalam penelitian sebanyak 1 kilogram yang diperoleh dari Pasar Pangandaran. Tepung gaplek digunakan sebagai bahan dalam pembuatan SOC. Air yang dibutuhkan dalam penelitian sebanyak 1 liter yang digunakan sebagai bahan dalam pembuatan SOC.

\section{Prosedur Penelitian}

Prosedur penelitian terdiri dari 2 tahapan kerja yaitu pembuatan dedak fermentasi, dan pembuatan silase rumput gajah.

\section{1) Tahap Pembuatan Dedak Fermentasi}

Dedak, SOC isi rumen dan molases dicampurkan sampai homogen dengan perbandingan 10: 2: 1 . Kemudian 
dipadatkan dan dimasukkan ke dalam toples. Campuran dedak tersebut disimpan selama 14 hari agar proses fermentasi berjalan dengan baik. Setelah dilakukan penyimpanan selama 14 hari, kualitas hasil dedak fermentasi dicek. Ciri-ciri dari dedak fermentasi yang baik yaitu: tekstur dedak lembab dan berwarna cokelat muda, memiliki aroma yang khas dengan wangi molases, tidak terdapat mikroorganisme seperti ragi, kapang, khamir, dan yeast.

\section{2) Tahap Pembuatan Silase}

Rumput gajah dilayukan selama \pm 24 jam. Rumput gajah dipotong dengan ukuran $4 \mathrm{~cm}$ dengan menggunakan golok. Kemudian, rumput gajah dan dedak fermentasi ditimbang sesuai dengan perbandingan dari perlakuan dan ulangan. Rumput gajah dan dedak fermentasi dicampurkan secara homogen kemudian dimasukkan ke dalam toples hingga padat agar tidak ada ruang untuk udara. Toples ditutup hingga rapat dan disimpan selama kurang lebih 7 hari. Suhu ruangan penyimpanan diukur menggunakan termometer digital infrared. Setelah dilakukan penyimpanan selama 7 hari, penutup toples dibuka untuk melihat kualitas silase. Sebelum pengambilan sampel, silase diaduk hingga homogen. Sampel diambil dari setiap toples sebanyak 500 gram untuk dilakukan uji lab. Pengambilan dilakukan dari 5 titik, diantaranya atas, kanan, kiri, tengah, dan bawah.

\section{Peubah yang Diamati}

Peubah yang diamati dalam penelitian yaitu kandungan bahan kering dan bahan organik silase rumput gajah.

\section{HASIL DAN PEMBAHASAN}

\section{Kandungan Bahan Kering}

Salah satu cara untuk mengetahui kualitas silase yang baik yaitu dengan melihat kandungan bahan kering silase. Silase dengan kandungan bahan kering yang tinggi lebih menguntungkan dibandingkan dengan silase yang mengandung bahan kering yang rendah. Hal ini karena pada saat kandungan bahan kering silase rendah maka silase tersebut mengandung banyak air. Bahan kering merupakan hasil dari pembagian fraksi yang berasal dari bahan pakan yang dikurangi kadar air. Kadar air bahan pakan dapat diketahui setelah bahan pakan dipanaskan pada oven dengan suhu $105^{\circ} \mathrm{C}$ selama 24 jam. Bahan kering dihitung berdasarkan selisih antara $100 \%$ dikurangi dengan persentase kadar air suatu bahan pakan yang dipanaskan hingga ukurannya tetap (Anggorodi, 1994). Berdasarkan data hasil penelitian, diperoleh kandungan bahan kering silase rumput gajah dengan penambahan dedak fermentasi seperti disajikan pada Tabel 1.

Tabel 1. Rataan Kandungan Bahan Kering Silase Rumput Gajah

\begin{tabular}{cccc}
\hline Ulangan & \multicolumn{3}{c}{ Perlakuan } \\
\cline { 2 - 4 } & P1 & P2 & P3 \\
\hline U1 & 16,34 & $\ldots \ldots \ldots \% \ldots \ldots \ldots$ & 22,83 \\
U2 & 17,53 & 21,05 & 16,67 \\
U3 & 17,90 & 19,88 & 19,70 \\
U4 & 17,68 & 19,08 & 19,37 \\
U6 & 18,14 & 21,11 & 16,89 \\
\hline Jumlah & 19,99 & 16,34 & 18,32 \\
\hline Rataan & 107,58 & 117,00 & 113,78 \\
\hline
\end{tabular}

Keterangan:

$\mathrm{P} 1=$ dedak fermentasi $1 \%$;

$\mathrm{P} 2=$ dedak fermentasi $3 \%$;

P3= dedak fermentasi $5 \%$.

Berdasarkan Tabel 1. dapat dilihat bahwa kisaran rataan kandungan bahan kering berkisar antara 17,93\%$19,50 \%$. Hasil analisis ragam menunjukkan bahwa penggunaan dedak fermentasi pada berbagai dosis tidak memberikan pengaruh yang nyata $(\mathrm{P}>0,05)$ terhadap kandungan bahan kering silase rumput gajah.

Penggunaan dedak fermentasi pada pembuatan silase rumput gajah mampu mempertahankan kandungan bahan kering. Hal ini karena tidak terjadi kerusakan atau degradasi bahan kering sehingga kandungan bahan kering tidak mengalami penurunan. Penurunan kadar bahan kering silase terjadi karena hilangnya bahan kering yang digunakan bakteri untuk terus menjalankan aktivitasnya (Kuncoro, 2015). Dedak fermentasi mampu mempertahankan kandungan bahan kering silase karena jumlahnya sebagai aditif cukup untuk aktivitas bakteri asam laktat.

Bakteri asam laktat pada silase rumput gajah dapat menghasilkan asam laktat dalam jumlah yang berlimpah sehingga menurunkan $\mathrm{pH}$. Penurunan $\mathrm{pH}$ ditandai dengan meningkatnya kandungan Asam laktat. Kandungan Asam laktat yang dihasilkan selama proses fermentasi akan berperan sebagai zat pengawet sehingga dapat mengurangi pertumbuhan mikroorganisme pembusuk. Meningkatnya proses pengawetan tersebut mampu menekan kehilangan nutrien yang terdapat pada silase. Hal ini sejalan dengan pendapat Santoso (2009), yang menyatakan bahwa kemampuan BAL yang diinokulasikan pada bahan silase mampu menurunkan $\mathrm{pH}$ sehingga dapat menghambat pertumbuhan bakteri clostridia, dan BAL akan menekan degradasi nutrien.

\section{Kandungan Bahan Organik}

Kandungan bahan organik suatu pakan terdiri atas protein kasar, lemak kasar, serat kasar dan bahan ekstrak tanpa nitrogen (BETN). Kandungan bahan organik merupakan selisih antara kandungan bahan kering dan kandungan abu. Kandungan abu suatu bahan pakan akan mempengaruhi kandungan bahan organiknya. Semakin tinggi kandungan abu maka 
kandungan bahan organik pakan tersebut akan semakin rendah.
Berdasarkan data hasil penelitian, diperoleh kandungan bahan kering silase rumput gajah dengan penambahan dedak fermentasi seperti disajikan pada Tabel 2.

Tabel. 2 Rataan Kandungan Bahan Organik Silase Rumput Gajah

\begin{tabular}{cccc}
\hline & & Perlakuan & \\
\cline { 2 - 4 } Ulangan & P1 & P2 & P3 \\
\hline & & $\ldots \ldots \% \ldots \ldots$ & 13,74 \\
U1 & 7,75 & 11,06 & 6,88 \\
U3 & 8,15 & 10,36 & 10,27 \\
U4 & 8,04 & 9,93 & 8,70 \\
U5 & 9,70 & 8,16 & 7,93 \\
U6 & 7,66 & 12,33 & 9,03 \\
\hline Jumlah & 9,42 & 5,05 & 56,55 \\
\hline Rataan & 50,72 & 9,89 & 9,43 \\
\hline
\end{tabular}

Keterangan:

$\mathrm{P} 1=$ dedak fermentasi $1 \%$;

$\mathrm{P} 2=$ dedak fermentasi $3 \%$;

P3= dedak fermentasi $5 \%$.

Berdasarkan data hasil penelitian, diperoleh kandungan bahan organik silase rumput gajah dengan penambahan dedak fermentasi yang disajikan pada Tabel 2. Dapat dilihat bahwa rataan kandungan bahan organik berkisar antara 8,45\%-9,82\%. Hasil analisis ragam menunjukkan bahwa penggunaan dedak fermentasi pada berbagai dosis tidak memberikan pengaruh yang nyata $(\mathrm{P}>0,05)$ terhadap kandungan bahan kering silase rumput gajah.

Tidak terdapatnya pengaruh perlakuan terhadap kandungan bahan organik silase terjadi karena penggunaan dedak fermentasi mampu menstimulir pembentukan asam laktat yang akan mengawetkan nutrisi yang terkandung dalam silase. Hal ini ditunjukkan dengan kandungan bahan organik yang jumlahnya tetap, tidak berubah, yang berarti bahan organik dapat terawetkan dengan baik.

Berdasarkan hasil penelitian penggunaan dedak fermentasi sebagai aditif dengan dosis 1-5\% akan mengoptimalkan proses ensilase dan mempercepat proses fermentasi, sehingga bakteri asam laktat akan optimal berkerja dan suasana asam berlangsung secara cepat. Yanti (2014) menyatakan bahwa silase akan terawetkan komposisinya jika ditambahkan dengan aditif. Penggunaan aditif berfungsi untuk mempercepat dalam proses ensilase untuk menghasilkan bakteri asam laktat sehingga nutrisi yang terdapat di dalam silase tersebut terawetkan. Menurut Supartini (2005) fungsi dari aditif adalah substrat terpenting bagi pengembangan bakteri asam laktat dan untuk mencegah penurunan nutrien dalam pembuatan silase.

\section{KESIMPULAN}

Penggunaan berbagai dosis dedak fermentasi dalam pembuatan silase rumput gajah tidak mempengaruhi kandungan bahan kering dan bahan organik silase rumput gajah. Penggunaan dedak fermentasi yang optimal dalam pembuatan silase rumput gajah ialah $1 \%$. Hal ini karena penggunaan 1-5\% hasilnya sama-sama mampu mengawetkan kandungan bahan kering dan bahan organik silase. Penggunaan dedak fermentasi yang disarankan dalam pembuatan silase sebaiknya menggunakan dosis $1 \%$. Hal ini karena dengan penggunaan $1 \%$ akan lebih ekonomis dibandingkan menggunakan dosis 3\% atau 5\%, karena menghasilkan kandungan bahan kering dan bahan organik yang sama.

\section{UCAPAN TERIMA KASIH}

Penulis mengucapkan terima kasih kepada pembimbing utama Ibu Dr. Ir. Budi Ayuningsih, M.Si. dan pembimbing anggota Ibu Dr. Iin Susilawati, S.Pt., MP. yang telah meluangkan waktu, nasehat dan bimbingan serta saran-saran yang diberikan sejak penyusunan proposal penelitian hingga penulisan skripsi dan Staff Laboratorium Nutrisi Ternak Ruminansia dan Kimia Makanan Ternak Fakultas Peternakan Universitas Padjadjaran yang telah membantu penelitian ini.

\section{DAFTAR PUSTAKA}

(AOAC) Association of Official Analytical Chemist. (19952005). Official Methods of Analysis, AOAC Arlington.

Anggorodi, R. (1994). Ilmu Makanan Ternak. PT Gramedia Pustaka Utama, Jakarta.

Arlini, A. E. (2014). Pengaruh Penambahan Isi Rumen dan Methionin pada Ransum Komersial Terhadap Gain dan Afisiensi Pakan Broiler. http://repository.pertanian.go.id/bitstream/handle/1234 56789/6958/30.\%20Revisi_132_Elma.Mklh\%20Poten si\%20Rumen\%20sapi.2016. new.pdf?sequence=1\&isA llowed=y (diakses 13 Desember 2020 jam 13.20).

Despal, I. G., Permana, S. N., Safarina, \& Tatra, A. J. (2011). Addition of Water Soluble Carbohydrate Sources Prior to Ensilage for Ramie Leaves Silage Qualities Improvement. Media Peternakan, Institut Pertanian Bogor, Bogor. 69-76.

Eko, D. J. (2012). Pengaruh Penambahan Urea Terhadap Kandungan Protein Kasar dan Serat Kasar Padatan Lumpur Organik Unit Gas Bio. Fakultas Peternakan, Universitas Brawijaya, Malang.

Kurnianingtyas, I. B., Pandansari, P. R., Astuti, I., Widyawati, S. D., \& Suprayogi, W. P. (2012). Pengaruh Macam Akselerator terhadap Kualitas Fisik, Kimiawi, dan Biologis Silase Rumput Kolonjono. Tropical Animal Husbandry, Institut Pertanian Bogor, Bogor. 7-14. 
Kuncoro, D. C., Mahtarudin, \& Fathul, F. ( 2015 ). Pengaruh Penambahan Berbagai Starter pada Silase Ransum Berbasis Limbah Pertanian terhadap Protein Kasar, Bahan Kering, Bahan Organik, dan Kadar Abu. Jurnal Ilmiah Peternakan Terpadu, Universitas Lampung, Lampung. 3(4); 234-238.

Nisa, M. U., Shahzad, M. S., Sarwar, M., \& Tauqir, N. (2008). Influence of Additives and Fermentation Periods on Silage Characteristics, Chemical Composition, and in Situ Digestion Kinetics of Jambo Silage and its Fodder in Nili Buffalo Bulls. Turkish Journal of Veterinary and Animal Sciences, 32; 67-72.

Sanderson, M. A., \& Paul, R. A. ( 2008). Perrenial Forages as Second Generation Bioenergy Crops. International Journal of Molecular Science, Switzerland. 768-788.

Santoso, B., Hariadi, B. T., Manik, H., \& Abubakar, H. (2009). Kualitas Rumput Unggul Tropika Hasil Ensilase dengan Aditif Bakteri Asam Laktat dari
Ekstrak Rumput Terfermentasi. Media Peternakan, Institut Pertanian Bogor, Bogor. 138-145.

Sinaga, R. 2007. Analisis Model Ketahanan Rumput Gajah dan Rumput Raja Akibat Cekaman Kekeringan Berdasarkan Respons Anatomi Akar dan Daun. Jurnal Biologi Sumatera. 2(1): 17-20.

Susetyo, Kismono, \& Soewardi, B. (1969). Hijauan makanan ternak. Direktorat Peternakan Rakyat Direktorat Jenderal Peternakan Departemen Pertanian., Jakarta.

Yanti, T. (2014). Kandungan Bahan Kering dan Bahan Organik Silase Beberapa Jenis Rumput Pakan Ternak dengan Additif Dedak Jagung. Universitas Mataram, NTB.

Supartini, \& Nonok. (2011). Penggunaan Onggok Sebagai Aditif Terhadap Kandungan Nutrien Silase Campuran Daun Ubi kayu dan Gamal. Buana Sains, 11 (1); 91-96. Universitas Tribhuwana Tunggadewi, Malang. 